\title{
アルケニルコハク酸系界面活性剤の脱墨効果
}

三菱石油侏研究本部開発研究所* 高橋 好夫, 武富 安昭

\section{Deinking Performance of Alkenyl Succinic Acid Base Surface Active Agent}

\author{
Yoshio Takahashi and Yasuaki Taketomi \\ Mitsubishi Oil Company Ltd., Research Headquaters, Research Laboratory for Development
}

\begin{abstract}
Recentry, utilization of deinked pulp increases extremely and deinking agent is becoming important.

Alkenyl succinic acid base surface active agents were synthesized to evaluate their performance in the deinking of waste newsprint.

The results are summarized as follows.

(1) The surface active agents made by the addition of ethylene oxide to alkenyl succinic acid monoalkyl ester showed best deinking performance.

(2) The optimum carbon number of alkenyl group in alkenyl succinic acid was 16 or 18 .

(3) EO mole number, in the range of 9 to 22, did not have much influence on deinking performance.
\end{abstract}

(4) The optimum carbon number of alkyl group was $1 \sim 3$.

Keywords : Deinking agent, Surface active agent, Alkenyl succinic acid, Flotation

\section{1. 緒言}

我が国の紙・板紙の生産は順調に伸びており，1988 年度の紙生産量は 1,475 万 $\mathrm{t}$, 板紙生産量は 1,040 万 $\mathrm{t}$ に達している1)。一方, 古紙回収率は 1984 年度の $50.7 \%$ ピークにやや低下し, 1988 年度は $47.5 \%$ まで 落ちたが2)，それは古紙回収量が増加し続けているに もかかわらず，それを上回る勢いで紙の使用量が増え ているためである。いずれにしても，原材料の半分が 古紙であり，1980 年のパルプ $58 \%$, 古紙 $42 \%$ に比べ, 古紙利用が急速に伸びていることが分る。

特に近年, 省資源・省エネルギーに加え, 森林資源 の保護をはじめとする地球環境保全対策, 大都市にお けるゴミ処理問題の解決, 中長期的視野からの製紙原 料の安定確保が叫ばれ, 古紙利用が国民的テーマおよ び世界的課題となりつつあり, 公的機関でも古紙回収

* 川崎市川崎区扇町 4-1 044 (344) 3147
に力を入れ，一部では製紙会社と共同で再生紙を開発 したり, 官民一体となって古紙再生運動を展開し効果 を上げている。

例えば，厚生省は今年 4 月より省内で使うコピー・ 印刷用紙を再生紙に全面的に切り替え, 環境庁, 通産 省でも昨年後半より一部部局で再生紙使用を始めてい る。また, 47 都道府県のうち庁舎全体で再生紙使用に 踏み切ったのが 13 都府県, 一部部局で使用しているの が 13 道県に上っている。

また民間でも，社内のコピー用紙を順次古紙再生紙 に切り替える企業が増えてきており, 経済新聞や業界 紙に古紙再生に関する記事が出ない日はないくらいに なってきている。

米国では, 資源保護の立場から新聞用紙のリサクイ ルを促進するための法制化に動く州が増えている。最 近ではメリーランド州，バーモント州，ミズーリ州， サウスダコタ州が再生新聞用紙の使用を強制的に行う 法律の成立に向けて動き, ニューヨークでは新聞社委 員会がニューヨーク州再生紙問題委員会の「2000 年ま 
でに新聞用紙使用量の $40 \%$ を再生紙にする。という 勧告を受けている。このように，日本以外の国々でも 古紙再生に真剣に取り組んでいる。

「古紙 $1 \mathrm{t}$ が直径 $14 \mathrm{~cm}$, 高さ $8 \mathrm{~m}$ の立木 20 本に相 当する。といわれていることから考えると，今後ます ます古紙再利用の気運は高まっていくであろう。

古紙の種類別の回収率を見てみてると, 1988 年度で 新聞 $90.4 \%$, 上質紙 $28.1 \%$ ，段ボール $68.9 \%$ であり， $\mathrm{OA}$ 機器に用いる情報用紙や主にカタログ, チラシに 使うコーテッド紙の回収・再生に目が向けられている 最近であるが，やはり新聞古紙が最も多く脱墨され再 生使用されている。

脱墨パルプを製造する工程は離解に始まり, 熟成, ニーディング，フローテーション，洗浄と順序はとも かくとして進んでいく。この時用いられる薬品は水酸 化ナトリウム, けい酸ナトリウムおよび湿潤, 乳化, 起泡, 洗浄作用を有している界面活性剤すなわち脱墨 鼡である。

ここ数年の脱墨剤の販売数量を見てみると, 1987 年 $6,400 \mathrm{t}, 1988$ 年 $7,000 \mathrm{t}$ (9.3\%増), 1989 年 $9,000 \mathrm{t}$ (28.6\%増) と年々伸長率が高くなっている3)。

日本で主に用いられているフローテーション法用脱 黑剤は従来脂肪酸あるいは高級アルコールのアルキレ ンオキサイド誘導体, 脂肪酸・脂肪酸石けんが用いら れてきたが, 新聞の印刷技術, 印刷方式の変化, 印刷 インキ成分の変化, 新聞のカラー印刷化および混入千 ラシのコート化・カラー印刷化, 中性紙における脱墨 パルプ配合率の増加などにともない, より高白色度, 低残インキ量, より高品質の DIP が要求されてきてい る。この要求に対応して, ハード面では高性能ニーダー の導入, フローテーターの改良および二段フローテー ターの導入等が行われているが, 薬品の面でも新しい タイプの高性能脱墨剤の開発が要望されている。そこ で, 脂肪酸と同様に, 疎水基としてのアルケニル基と 親水基としてのカルボキシル基を有するアルケニルコ 八ク酸を脱墨剤原料として使用した場合の脱墨性能に ついて検討し, インキ捕集性, 凝集性, 起泡性に優れ, さらに末剝離インキ(いわゆる“ヒゲ状インキ”) の少 ない良好な脱墨剤を得たので，その詳細を以下に紹介 する。

\section{2. 実験}

\section{1 脱 壘 剤}

(1) アルケニルコハク酸モノアルキルエステル

各種オレフィンと無水マレイン酸を 150 ～250 ${ }^{\circ} \mathrm{C}$ 下 で加熱反応して得られた付加反応物をメチルアルコー
（1）アルケニルコハク酸モノアルキルエステル

$$
\begin{gathered}
\mathrm{R}_{1}-\underset{\text { I }}{\mathrm{CH}}-\mathrm{COO}-\mathrm{R}_{2} \\
\mathrm{CH}_{2}-\mathrm{COOH}
\end{gathered}
$$

（2）アルケニルコハク酸モノアルキルエステル アルキレンオキサイド付加物

$$
\begin{gathered}
\mathrm{R}_{1}-\underset{\mathrm{CH}}{\mathrm{C}}-\mathrm{COO}-\mathrm{R}_{2} \\
\mathrm{CH}_{2}-\mathrm{COO}-(\mathrm{AO})_{n} \mathrm{H}
\end{gathered}
$$

（3）アルケニルコハク酸アルキレンオキサイド付加物

$$
\begin{array}{r}
\mathrm{R}_{1}-\underset{\mid}{\mathrm{CH}}-\mathrm{COO}-(\mathrm{AO})_{\mathrm{n}} \mathrm{H} \\
\mathrm{CH}_{2}-\mathrm{COO}-(\mathrm{AO})_{\mathrm{m}} \mathrm{H}
\end{array}
$$

( $\mathrm{R}_{1}$ はアルケニル基, $\mathrm{R}_{2}$ はアルキル基, $\mathrm{AO}$ は (アルキレンオキサイド， $\mathrm{n}, \mathrm{m}$ は付加モル数を示す。

図 1 アルケニルコハク酸系脱墨剤の構造 ル等の低級アルコールでモノエステル化して目的の脱 墨剤を得た。

(2) アルケニルコハク酸モノアルキルエステルの アルキレンオキサイド付加物

各種オレフィンと無水マレイン酸を $150 \sim 250^{\circ} \mathrm{C}$ 下 で加熱反応して得られた付加反応物をメチルアルコー ル等の低級アルコールでモノエステル化したものに， エチレンオキサイド (EO) およびプロピレンオキサイ ド（PO）を付加して目的の脱墨剤を得た。

(3) アルケニルコハク酸アルキレンオキサイド 付加物

オレフィンと無水マレイン酸を 150 ～ $250^{\circ} \mathrm{C}$ 下で加 熱反応して得られた付加反応物を水と反応させアルケ

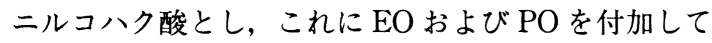
目的の脱墨剤を得な。

上記 3 種類の脱墨剤の構造を図 1 に示す。

\section{2 脱畦試験}

脱墨試験は J. TAPPI 脱墨試験方法 (No.39-82, 「古 紙の脱インキ試験方法」) に準拠して行った。

(1) 古紙, 試薬

古紙として印刷後 1 ～ 2 ケ月経過した毎日，朝日， 読売新聞を各 $1 / 3$ づつ混合した新聞古紙 $70 \%$, チラシ 30\%を配合したものを裁断して用いた。無機薬品であ る水酸化ナトリウム, 3 号けい酸ナトリウム, 過酸化 水素はいずれも試薬一級をそのまま用いた。

(2) 脱墨方法

(1)離解：新聞古紙を $15 \times 7 \sim 8 \mathrm{~mm}$ の大きさに裁断し, 容量 $5 l$ の卓上離解機に入れ, その中に温水, 水酸化ナトリウム, 3 号けい酸ナトリウム, 過 酸化水素 (純分), 脱墨剂を加え, 離解した(パ 
表 1 脱墨試験条件

\begin{tabular}{|c|c|c|c|c|}
\hline & 離 解 & 熟 成 & $\begin{array}{l}\text { フロー } \\
\text { テーション }\end{array}$ & 洗 浄 \\
\hline パルプ濃度 $(\%)$ & 5 & 5 & 1 & $1 \rightarrow 10$ \\
\hline 度 $\left({ }^{\circ} \mathrm{C}\right)$ & $50 \sim 60$ & 50 & 30 & - \\
\hline 間（分） & 10 & 60 & 20 & - \\
\hline 水酸化ナトリウム & 2.0 & - & - & - \\
\hline 3 号けい酸十トリウム & 4.0 & - & - & - \\
\hline 過酸化水素(純分) & 2.0 & - & - & - \\
\hline 脱 墨 剂 & 0.2 & - & - & - \\
\hline
\end{tabular}

*薬剤添加量は対古紙当りの重量 $\%$

ルプ濃度 $5 \%$ )。

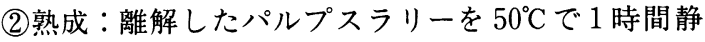
置, 熟成した。

(3)フローテーション：

パルプ濃度を $1 \%$ まで希釈した後, $5 l$ の空気 吸い込み式のテーブルテスト用フローテー ターに移し，フローテーションを行った。フ ローテーション時間は脱墨剤の効果差をより 明確にするため 20 分とした。 このフローテーション時にオーバーフローし た泡および約 30 秒毎に搔き出した泡の重量 の多少により起泡性の良否を判定した。

(4)洗浄：100メッシュのポリエチレン網を用いて, パ ルプ濃度 $10 \%$ まで洗浄脱水した。

(5)抄紙：TAPPI スタンダードマシンを用いて抄紙し， 回転ドライヤーで乾燥して坪量 $80 \mathrm{~g} / \mathrm{m}^{2}$ の パルプシートを作製した。

6)白色度, 残インク量

測色色差計にてシートの白色度を測定した (JIS Z 8722-1982 準拠)。また, 画像解析装置 にて残インク量 (数, 面積) を測定した（直 径約 $2.5 \mu$ までのインク粒子を測定するとと もに，シート中に残っている褐色の樹脂まで 測定可能なシビアーな条件で測定した。)

(7)なお, 脱墨条件, 薬剤添加率については表 1 に示す。

\section{3. 結果と考察}

3.1 アルケニルコハク酸モノアルキルエステル

（1）アルケニル基の炭素数の脱墨効果への影響

(図 2 )。

アルケニル基の異なる（炭素数 $9 ， 12 ， 14 ， 16,18$, 20）種々のアルケニルコハク酸を用いて，アルケニル

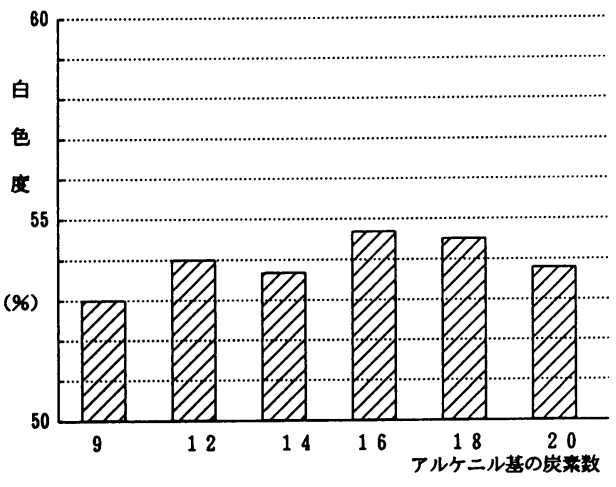

図 2 アルケニルコハク酸モノイソプロピルエステ ルのアルケニル基の炭素数の脱墨効果への影 響

コハク酸モノイソプロピルエステルを調製し，表 1 の 条件で脱墨効果を比較した。

その結果, アルケニル基の炭素数が 9 から 18 に大き くなるにしたがって, 白色度は増加傾向にあり, 16〜18 より大きくなると白色度はやや低下する傾向を示した。 したがって，アルケニル基の炭素数は 16 または 18 が 好適であると考えられる。

（2）アルキル基の炭素数の脱墨効果への影響 (図 3 )

アルケニル $\left(\mathrm{C}_{16}\right)$ コハク酸モノアルキルエステルの アルキル基を炭素数 1 から 8 (メチル, エチル, イソプ ロピル，n-ブチル，イソブチル，2-エチルヘキシル） まで変えた時の脱墨効果への影響について検討した。 その結果, アルキル基の炭素数 1〜4程度では脱墨効果 への影響はあまりないが（炭素数 8 ではやや脱墨効果 が低下する。，起泡性はアルキル基の炭素数が大きく なるほど小さくなる傾向を示した。

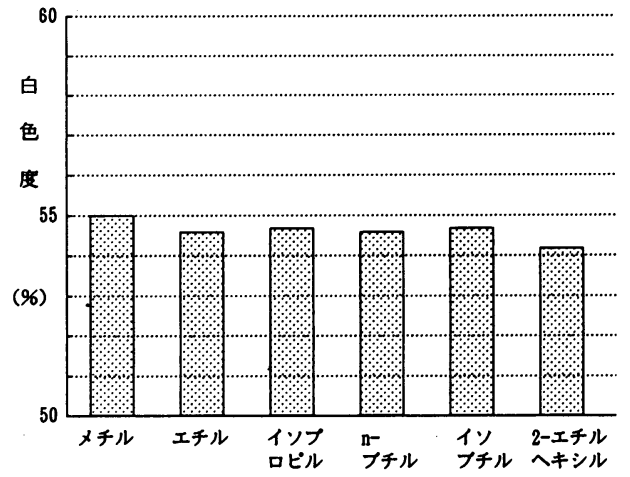

図 3 アルケニル $\left(\mathrm{C}_{16}\right)$ コハク酸モノアルキルエス テルのアルキル基の炭素数の影響 


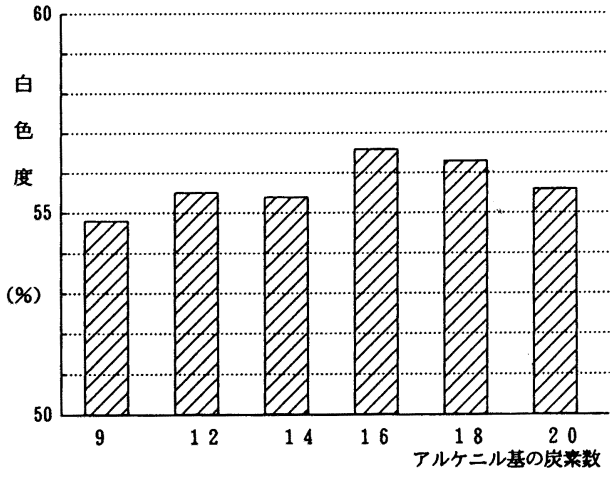

図 4 アルケニルコハク酸モノイソプロピルエステ ルエチレンオキサイド付加物のアルケニル基 の炭素数の脱墨効果への影響

\section{2 アルケニルコハク酸モノアルキルエステルエ チレンオキサイド付加物}

(1) アルケニル基の炭素数の脱墨効果への影響 (図 4 )

アルケニル基の異なる（炭素数 $9 ， 12 ， 14,16,18$, 20）種々のアルケニルコハク酸を用いて，アルケニル コハク酸モノイソプロピルエステルのエチレンオキサ イド 13 モル付加物を調製し, 表 1 の条件で脱墨効果を 比較した。

その結果, 3.1 (1)と同様にアルケニル基の炭素数が 9 から 18 に大きくなるにしたがって, 白色度は増加傾 向にあり，16〜18より大きくなると白色度はやや低下 する傾向を示した。したがって，アルケニル基の炭素 数は 16 または 18 が好適であると考えられる。

(2) $\mathrm{EO}$ 付加モル数の脱墨効果への影響（図 5 )

アルケニル $\left(\mathrm{C}_{16}\right)$ コハク酸モノメチルエステルにモ ル数の異なる $\mathrm{EO}$ を付加して脱墨効果を比較したとこ ろ, モル数 9 22 の範囲では $\mathrm{EO}$ 付加モルの影響はあ まり認められなかった。

（3）アルキル基の炭素数の脱墨効果への影響 (図6)

アルケニル $\left(\mathrm{C}_{16}\right)$ コハク酸モノアルキルエステルエ チレンオキサイド付加物の場合, 同一 EO 付加モル数 ではメチル基，イソプロピル基およびイソブチル基の 脱墨効果にあまり差はなかったが，2-エチルへキシル 基の場合は気泡性が低下し, 脱墨効果も低下した。し かし，イソブチル基，2-エチルへキシル基の場合，メ チル基，イソプロピル基に比べ水溶性が低下し，また， 水溶性を高めるためには $\mathrm{EO}$ 付加モル数を大きくする 必要が生じ，結果的に常温で固体となってしまうため, 取扱い上は ASA (16) (メチル) (EO) ${ }_{13}$, ASA (16) (イ

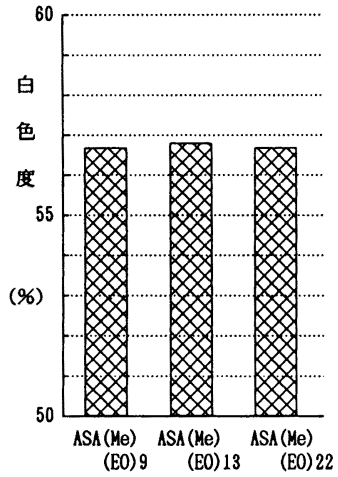

図 5 アルケニル $\left(\mathrm{C}_{16}\right)$ コハク酸モノメチルエステ ルエチレンオキサイド付加物のエチレンオキ サイドの付加モル数の影響

(注) 図中の $\mathrm{Me}$ はメチル

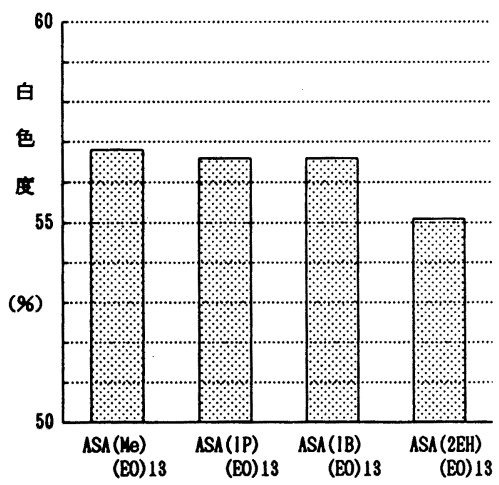

図 6 アルケニル $\left(\mathrm{C}_{16}\right)$ コハク酸モノアルキルエス テルエチレンオキサイド付加物のアルキル基 の炭素数の影響

(注) 図中の Me はメチル, IP はイソプロピル, IB は イソブチル，2EHは2-エチルヘキシルを示す。

ソプロピル) $(\mathrm{EO})_{13}$ 等が好適である。

[ここでASA (16) はアルケニル基の炭素数が 16 の アルケニルコハク酸を示す。]

\section{3 アルケニルコハク酸アルキレンオキサイド付 加物}

(1) アルキレンオキサイド付加モル数の脱墨効果へ の影響 (図 7 )

アルケニル $\left(\mathrm{C}_{16}\right)$ コハク酸アルキレンオキサイド付 加物のアルキレンオキサイドを,

ASA $\left(\mathrm{C}_{16}\right)(\mathrm{EO})_{4}(\mathrm{EO})_{9}$

ASA $\left(\mathrm{C}_{16}\right)(\mathrm{EO})_{4}(\mathrm{EO})_{13}$

ASA $\left(\mathrm{C}_{16}\right)(\mathrm{EO})_{9}(\mathrm{EO})_{9}$

ASA $\left(\mathrm{C}_{16}\right)(\mathrm{EO})_{13}(\mathrm{EO})_{13}$ 


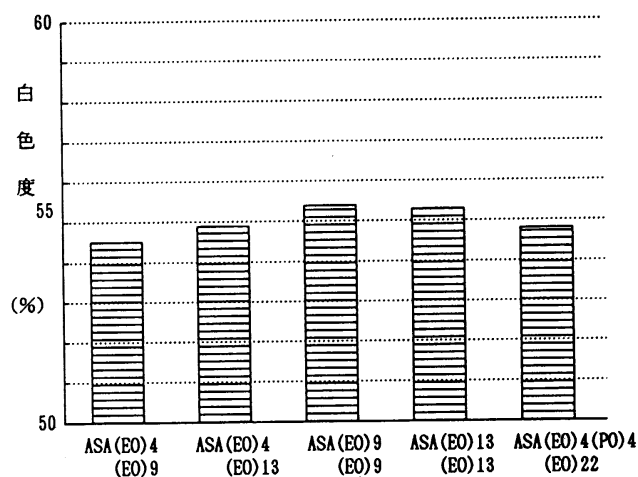

図 7 アルケニル $\left(\mathrm{C}_{16}\right)$ コハク酸アルキレンオキサ イド付加物のアルキレンオキサイドの付加モ ル数の影響

$\operatorname{ASA}\left(\mathrm{C}_{16}\right)(\mathrm{EO})_{4}(\mathrm{PO})_{4} \cdot(\mathrm{EO})_{22}$

と変えた時の脱墨効果への影響について検討した。

その結果, この程度の範囲の付加モル数の違いによ る影響はあまりないが, 前項同様 $\mathrm{EO}$ 付加モル数が

$\operatorname{ASA}\left(\mathrm{C}_{16}\right)(\mathrm{EO})_{4}(\mathrm{EO})_{9}$ のように小さ過ぎると水へ の溶解性が低下し,

$\operatorname{ASA}\left(\mathrm{C}_{16}\right)(\mathrm{EO})_{13}(\mathrm{EO})_{13}$ のように大き過ぎると常 温で固体となってしまうため取扱上は,

$\operatorname{ASA}\left(\mathrm{C}_{16}\right)(\mathrm{EO})_{4}(\mathrm{EO})_{13}$

$\operatorname{ASA}\left(\mathrm{C}_{16}\right)(\mathrm{EO})_{9}(\mathrm{EO})_{9}$

等が好適である。また, $\mathrm{PO}$ 付加の場合, 水への溶解性 を低下させないために，EO 付加モル数を大きくする 必要が生じ, 結果的に固体となり好ましくない。

3.4 構造の異なる脱墨剤の比較（図 8,9）

前項 3.1, 3.2, 3.3 で示した構造の異なる 3 種類の 脱墨剤の効果を比較すると, アルケニル $\left(\mathrm{C}_{16}\right)$ コハク

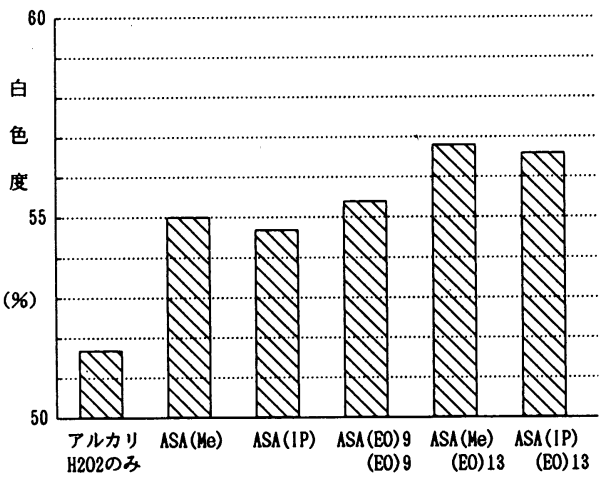

図 8 各種構造を有する脱墨剤の脱墨効果(白色度)

(注) 困中の $\mathrm{Me}$ はメチル, IP はイソプロピルを示 す。

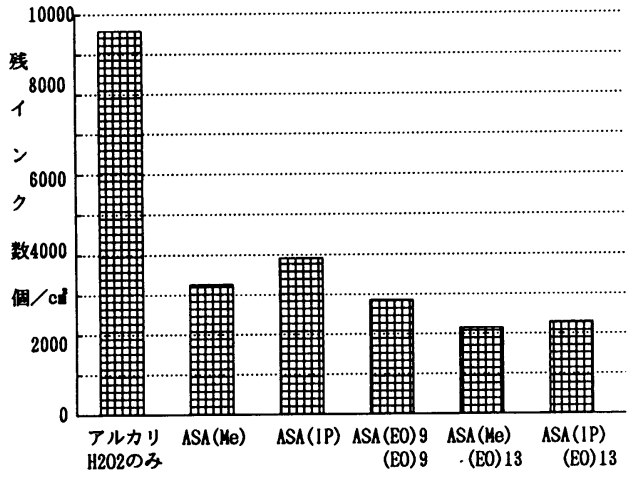

図 9 各種構造を有する脱墨剂の脱墨効果 (残インク数)

(注) 図中の Me はメチル, IP はイソプロ ピルを示す。

酸モノアルキルエステルエチレンオキサイド付加物 [図 8 および図 9 中の

$\operatorname{ASA}\left(\mathrm{C}_{16}\right)$ (メチル) $(\mathrm{EO})_{13}$ および $\mathrm{ASA}\left(\mathrm{C}_{16}\right)$ (イソプロピル) $\left.(\mathrm{EO})_{13}\right]$ が最も効果が優れており，また，残インク数も少ない 傾向を示し， 3 種類の中では起泡性も最も良い傾向を 示した。また，二塩基酸のため，この脱墨剤はインキ の捕集性および凝集性に優れていることが，フロー テーション工程でのフロス（泡）の黒さから観察され た。

\section{5 添加量変化（図 10, 11）}

アルケニル基の炭素数が $\mathrm{C}_{16}$ の ASA（イソプロピ ル) $(\mathrm{EO})_{13}$ を用いて, 添加量を変えて脱墨効果を比較 したところ，0.35\%以上では白色度, 残インク数に頭 打ちの傾向が見られた。一般の脱墨剤でも同様の傾向 が見られることから, 脱墨剤は添加し過ぎても脱墨効

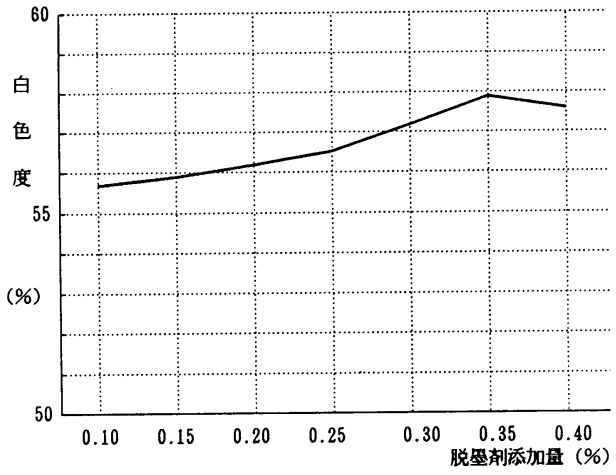

図 10 添加量変化 $\left[\mathrm{ASA}\left(\mathrm{C}_{16}\right)(\mathrm{IP})(\mathrm{EO})_{13}\right]$ (白色度) 


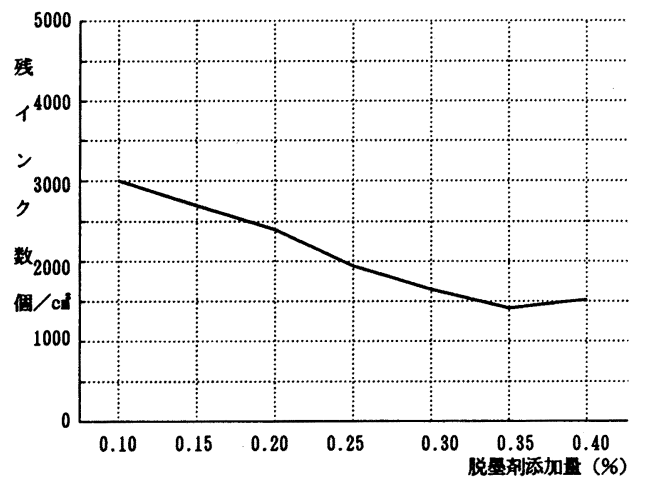

図 11 添加量変化 $\left[\mathrm{ASA}\left(\mathrm{C}_{16}\right)(\mathrm{IP})(\mathrm{EO})_{13}\right]$ (残インク数)

果にほとんど寄与しないことが分る。

\section{4. 結 論}

アルケニルコハク酸系の脱墨剤について, その構造 と脱墨効果の関係について種々検討した結果, 以下の 結論を得た。

(1) アルケニルコハク酸 (ASA) モノアルキルエス
テルエチレンオキサイド付加物が良好な脱墨効果を示 した。

（2）アルケニル基の炭素数は 16 または 18 の場合が 最も高い白色度を示した。

(3) アルケニルコハク (ASA) モノアルキルエステ ルエチレンオキサイド付加物のアルキル基の炭素数お よび $\mathrm{EO}$ 付加モル数の影響はさほどないが，取扱い上 液状であることが望ましいことを考虑すると，

ASA (メチル) $(\mathrm{EO})_{13}$

ASA (イソプロピル) $(\mathrm{EO})_{13}$

等が適当である。

\section{参考文献}

1) 紙パルプ統計年報 (昭和 63 年) 通産大臣官房調査 統計部編

2）古紙統計年報（1988 年度版）古紙再生促進セン 夕一

3）紙パルプ産業白書 (1988 年〜1990 年版) 矢野経済 研究所

4）特開 平 1-306690, 306691 